\title{
Researching higher education in Africa as a process of meaning-making: Epistemological and theoretical considerations
}

\section{Michael Cross}

Ali Mazrui Centre for Higher Education Studies, University of Johannesburg, Johannesburg, South Africa (succumbed to the COVID-19 virus on 6 June 2021)

\section{Logan Govender}

Ali Mazrui Centre for Higher Education Studies, University of Johannesburg, Johannesburg, South Africa lvgovender@uj.ac.za;

https://orcid.org/0000-0002-2889-2827

(Received: 26 November 2020; accepted: 18 June 2021)

\section{Abstract}

In this article, we argue for a new way of thinking about knowledge construction in African higher education as a basis for developing new theoretical and epistemological insights, founded on inclusivity, epistemic freedom, and social justice. We recognise coloniality as a fundamental problem that needs us to scrutinise our knowledge of decolonisation (about decolonisation itself) and our knowledge for decolonisation (to make change possible). Following Bourdieu (1972), such thinking also requires degrees of vigilance that entail fundamental epistemological breaks, or put differently, it requires epistemological decolonisation as a point of departure. Thus, the future of tertiary education in Africa must be located within a new horizon of possibilities, informed by a nuanced political epistemology and ontology embedded in the complex African experience and visibility of the colonised and oppressed. In short, there can be no social justice without epistemic justice.

Keywords: African higher education, alternative thinking, epistemological decolonisation, social justice

\section{Introduction}

Researching higher education in Africa raises serious epistemological and theoretical challenges. This is largely because African higher education research has relied on Western models, paradigms, assumptions, concepts, methodologies, and procedures, among other research related aspects. Western hegemony and ideology have influenced and continue to influence the epistemologies, theories, methods, and outcomes of higher education research 
in Africa (Oparinde \& Govender, 2019). Western claims to scientific rationality, universality, objectivity, and neutrality have dominated our research paradigms to the detriment of alternative approaches and conceptions of knowledge. More suitable approaches and methods aligned to the African context are often unrecognised and thus underused despite the calls for decolonial research methods (Chilisa, 2012). Our fundamental proposition is the need to think differently about knowledge construction in African higher education as a basis for developing new theoretical and epistemological insights. We begin with a literature review of emerging decolonial constructs and alternative epistemologies that encompass three generations of scholarship. We then present the key arguments before outlining a conceptual framework to inform higher education research meaning making and practices in Africa. We conclude by highlighting the value and relevance of the theoretical and epistemological propositions offered.

\section{Literature review}

Current literature has highlighted crimes committed by the West in Africa: colonial genocides and the notion of the theft of history (Goody, 2006), epistemicides (killing of indigenous people's knowledges) and linguicides (killing of indigenous people's languages), culturecides (killing of indigenous people's cultures) (Ndlovu-Gatsheni, 2018a; wa Thiong'o, 2009, 2012). Contestation of these crimes has given rise to at least three generations of scholarship. The first generation centred on reclaiming African origins and authenticity by exploring African pre-colonial historical achievements. It emphasised revisiting narratives of the colonial experience (colonial subjugation and exploitation on the one hand, and resistance, co-option, and liberation, on the other), a task undertaken by progressive Western Africanists and the emerging generation of African scholars (Diop, 1954; Ki-Zerbo, 1994). Notable is Mazrui's (1986) Triple Heritage that distilled the key influences-African culture, Islamic culture, and Western culture-in the constitution of Africa.

The second generation was comprised of two streams. The first stream that started with scholars like Nkwame Nkrumah, Francis Fanon, Leopold Senghor, Es'kia Mphahlele, Steve Biko, and Neville Alexander was concerned with the discovery of African unity, Négritude, Black consciousness, African identities, Africanness, and the struggles of the colonised towards liberation. The other stream entailed an intensive debate on the reproduction of colonialism or coloniality in the post-independence period supported by the Review of Political Economy and the New Left Review. Drawing on Marxist theories, it focused on the nature of the post-colonial state, power, and the reproduction of neo-colonial forms of dependence and exploitation after independence, particularly in the School of Dar-es-Salaam (e.g. Amin, 1972; Rodney, 1972; Shivji, 1976), the Centro de Estudos Moçambicanos in Maputo (e.g. Ruth First, Robert Davis, Barry Munslow, and Jacques Depelchin), and the proliferation of neo-Marxist analyses in Southern African studies (e.g. Dan O'Mara, Mike Morris, Harold Wolpe, and Charles Van Onselen). With very few exceptions (e.g., Jacques Depelchin's and Ali Mazrui's critiques), the radical scholarship pursued by this generation bears some responsibility for the Western modernity project in Africa. 
The third generation entails the search for alternative epistemologies and methodologies more responsive to the social and economic complexities of the continent (e.g., Devisch \& Nyamjoh, 2011; Hountondji, 1983, 1997, 2002, 2013; Mawere, 2011; Nabudere, 2011a, 2011b; Zeleza, 1997). It has provided new analytical concepts, including epistemic freedom as opposed to academic freedom, provincialisation of the West, deprovincialisation of Africa, epistemological decolonisation, intellectual extroversion to reclaim our rightful place at the global stage, and epistemic dependence, epistemic disobedience, de-bordering, decentering/de-peripherising, delinking, colonial difference, de-westernisation and decolonialising higher education research, and decolonial theory (Cossa, 2009; NdlovuGatsheni, 2018b). This is very often associated with slogans such as Africa [up]rising (displaying a narrative of success) as Branch and Mapilly (2015) use in the title of their edited collection, African awakening as Manyi and Ekine (2012) use in their title, along with African revival and Africanacity or the African ability to meet every challenge with tenacity, ingenuity, positivity, and creativity, ${ }^{1}$ without forgetting the on and off African Renaissance. Latin American scholars, such as Anibal Quijano, Ramon Grosfoguel, Nelson MaldonadoTorres, and Walter Mignolo have also contributed significantly to decolonial thought and the higher education project. Grossfoguel (2007, p. 214), has argued that "[b]y delinking the ethnic/racial/gender/sexual epistemic location from the subject that speaks, Western philosophy and sciences are able to produce a myth about a Truthful universal knowledge." Likewise, Quijano (2000), argued for a conceptualisation of the present world-system as a historical-structural heterogeneous totality that he called a "colonial power matrix" that affects all dimensions of social existence such as sexuality, authority, subjectivity, and labor (cited in Grosfoguel, 2007, p. 217)

Significantly, the concept of coloniality has its roots in the writings of Latin American decolonial scholars Anibal Quijano (2000) and Walter Mignolo (2000); the latter explained that coloniality is the "darker side" of modernity and should be unveiled (cited in Seroto, 2018 , p. 3). ${ }^{2}$

Common to concerns about de-bordering, de-centering, and de-provincialising is the belief that central concepts and propositions in research do not originate in, or privilege, a single culture, but are derived from, and are relevant to, multiple cultures (Rivenburgh \& Manusov, 2010). At the analysis stage, researchers must be mindful, once again, of the influence of their own cultural mindsets when explaining phenomena in a different cultural setting.

1 Absa, a South African bank that serviced a predominantly white Afrikaner clientele during apartheid has been promoting this concept in the democratic era, explaining it as a "[n]ew word for our new purpose. There is a way of doing things that is unique to our continent. Of meeting every challenge with tenacity, ingenuity, positivity, and creativity. At Absa, we call this Africanacity: the distinctly African ability to always find ways to get things done." Coloniality should not be confused with colonialism; it refers to the long-standing patterns of power that have emerged as a result of colonialism that define "culture, labour, inter-subjectivity relations, and knowledge production well beyond the strict limits of colonial administrations" Maldonado-Torres (2007, p. 243). Decolonisation refers to the absence of a condition of coloniality. The suffix isation suggests the act of becoming, the process of transcending coloniality, a process that takes place in an interconnected, dynamic, and changing world. For Césaire (2000, cited in Heleta, 2016, p. 5), "decolonisation is about the consciousness and rejection of values, norms, customs and worldviews imposed by the [former] colonisers." 


\section{Emerging discourses: Epistemologies of the South, Decolonising methodologies, and other alternative discourses}

The epistemologies of the South placed the notions of a plurality of knowledges, different knowledges, and multiple locations of knowledge — multiple epistemologies — on the agenda and thus gave recognition and legitimation to the presence of subjugated knowledges or silenced voices. They brought to the forefront the idea "that all groups have a right to speak for themselves, in their own voice, and have that voice accepted as authentic and legitimate" (Harvey, 1989, p. 48). The objective of the epistemologies of the South is to allow the oppressed social groups who suffered the destruction caused by capitalism, colonialism, patriarchy, archaism, racism, sexism, Christian-centrism, hetero-normativity, geographical provincialising, homophobia, and misogyny to represent the world as their own and in their own terms (Ndlovu-Gatsheni, 2018b; Santos, 2014). It is a project that strives for recognition of new ecologies and cartographies of knowledge (Barreto, 2014; Cross et al., 2019; Santos, 2007, 2014; Santos et al., 2007).

Decolonising methodologies opened a new research tradition in the production of knowledge (Archibald et al., 2019; Cochran et al., 2008; Datta, 2018; Denzin et al., 2008; Simpson, 2001; Smith, 2005, 2012; Zavala, 2013). Methodology has been defined by Smith (2012, p. ix) as "the theory of method, or the approach or technique being taken, or the reasoning for selecting a set of methods." In Decolonising methodologies: Research and Indigenous peoples (2012) she is concerned "not so much with the actual technique of selecting a method but much more with the context in which research problems are conceptualized and designed, and with the implications of research for its participants and their communities" (p. ix). Decolonising methodologies aims to disrupt "relationships between researchers (mostly nonindigenous) and researched (indigenous), between a colonizing institution of knowledge and colonized peoples whose own knowledge was subjugated, between academic theories and academic values, between institutions and communities, and between and within indigenous communities themselves" (Smith, 2012, p. x). In doing so, this work challenges the institution of research, its claims, its values and practices, and its power dynamics with reference to the content of knowledge, the absences, silences and invisibilities of other peoples, practices and ethics, and implications for communities of research (Smith, 2012). Decolonising methodologies is not against research but is "for new ways of knowing and discovering, and new ways to think about research with indigenous peoples" (Smith, 2012, p. 4). Briefly, it is about researching as a self-discovery strategy.

The notion of decolonising methodologies rests on a political epistemology grounded in the principles of human rights, democracy, and social justice that takes the value of participation and consultation in knowledge production seriously. Inspired by Fanon's (1965) call to voice, Linda Tuhiwai Smith's (2012) Decolonising Methodologies challenges the way research has been used by European colonial powers to subjugate Indigenous peoples. She lays out methodological principles for indigenous research that do not reproduce the same dehumanising results for which colonial knowledge production has been responsible. Quoting Lather (1991), Smith (1999, p. 3) disrupts "the rules of the research game towards practices 
that are more respectful, ethical, sympathetic and useful versus racist practices and attitudes, ethnocentric assumptions and exploitative research." In Decolonising Educational Research, Patel (2015) calls for ownership and answerability (to Indigenous people, to colonised peoples on Indigenous land, and to Black people on Indigenous land).

Asante $(1987,2015)$ argued that concepts and methods in Western thought are inadequate to explain all the possible ways of knowing because universality cannot be a product of one culture. In other words, since no culture is universal, no culture can generate universally valid knowledge. Therefore, all cultures, including the indigenous ways of knowing arising from them, deserve to be respected and valued in their uniqueness. This means that African higher education research, theory, and methods should acknowledge and include the African ways of knowing, and value African ontologies, epistemologies, and ethics (Mazama, 2001; Oyebade, 1990; Schiele, 1994). The argument is that research methods need to be aligned with the intentions, context, and participatory nature of indigenous knowledge systems. In this regard, many theorists advocate for a paradigm, an approach, theory, and methods rooted in Afrocentricity (Asante, 1987; Mazama, 2001).

Beyond confronting Western epistemological and theoretical hegemony, these emerging discourses have shed some light on how knowledge is produced and controlled in our institutions, on knowledge advancement across the continent, and on the interplay of power and politics of knowledge. In similar vein, Fataar (2018), called for a type of cognitive justice based on an overhaul and expansion of the Western knowledge canon. Decoloniality, Fataar (2018) argued, offers three curriculum knowledge claims: claim one (drawing on Santos, 2014 ) is based on the centering of an all-inclusive ecology of knowledge approach; claim two, the knowledge and identity claim, is based on the productive recognition and restoration of the full dignity of subjugated peoples aimed at unearthing their full human potential; and claim three pivots on knowledge relevance and contextualisation - the idea that curriculum knowledge ought to make epistemological connections to the knowledges of people, their contextual life circumstances, indigenous knowledge systems, languages, and ways of knowing.

Thus, these scholars have played an important role in steering the South-South debate, particularly the epistemologies of the South movement, and tackling important issues such as the production and dissemination of knowledge relevant to the African context. They have shown that we can challenge the dominance of Eurocentrism without falling into an intellectual and discursive ghettoisation. They have redefined the role of academics, policymakers, and curriculum and programme designers in dealing with coloniality in policies, research, knowledge, and pedagogy. Put differently, this is about how to reframe our understanding of, or engagement with, knowledge production, utilisation, and its assessment. In this sense, these discourses are a crusade for self-discovery, recognition, and global scholarly affirmation of Africa.

There is now increasing realisation that the struggle for positive representation and recognition of Africa in the global intellectual arena must mirror the real experiences, needs, and aspirations of African people, not simply the negative and often depressing 
representations of them seen from the perspective of a colonial or Western epistemological frame. The time has come for researchers, academics, administrators, critics, analysts, and students of higher education in Africa to cast the net widely, flex their intellectual muscles, and refuse to confine their visions, analyses, and praxis to the idea of the university as preconceived and long prescribed by the colonial past. In this sense, the experiences of African people are an important subject, as opposed to being mere objects of study, central to which is an adequate contextualisation of knowledge and visibility of the oppressed. For example, in the course of 2020, African-based medical solutions to combat the COVID-19 pandemic have emerged but have met with little serious consideration by the Western-dominated mainstream global medical fraternity. Part of the challenge lies in the lack of support for indigenous knowledge systems to thrive, including traditional medical treatments that can be used for symptoms associated with COVID-19 (Yew-Siong and Ally, 2020). As Mudimbe (1985, p. 206) asserted, academics need to establish themselves and their societies "as 'subjects' of their own destiny" as well as to reinvent their past and envision their future.

However, scholars and education practitioners must take this opportunity to step back and interrogate the discourses embedded in the legacy of critique by the West, and its assumptions about global power dynamics and power relations in the domain of knowledge. The primary challenge in this context is for us to dare recast, redefine, and revise the very notions of research, epistemology, knowledge, and knowledge application to establish a solid platform for meaningful change in our universities and scholarship.

\section{Argument}

The argument posits four key claims. First, beyond the current critique of Western hegemony, what are urgently needed are not necessarily alternatives but, instead, alternative thinking about the epistemological, theoretical, and methodological foundations of knowledge in African higher education. Second, such thinking should be grounded not only in full acknowledgement of the centrality of epistemic freedom and justice, but also in the recognition of "coloniality as a fundamental problem in the modern age" (Ndlovu-Gatsheni, 2014, p. 185; see also Maldonado-Torres, 2007; Mignolo, 2007b, 2011; Mignolo \& Escobar, 2010; Mignolo and Vasquez, 2013; Ndlovu-Gatsheni, 2013, 2014; Quijano, 2000; Seroto, 2018). Third, as suggested by the Western scholar, Bourdieu (1988), in the domain of social research, such thinking also requires degrees of vigilance that entail fundamental epistemological breaks. This idea was reiterated by Mudimbe (1988) in The invention of Africa: Gnosis, philosophy, and the order of knowledge, where he highlighted the imperative of continually exercising epistemological vigilance. Fourth, careful attention should be paid to the nature of the knowledge for and knowledge of transformation-the call for not only a specific political, moral, and ethical responsibility but also adequate and perpetual epistemic vigilance to account for the complexities of the African context in its diversity.

Overall, confronting this challenge requires carefully considered epistemological, theoretical, and methodological bases, revisiting existing concepts and assumptions, creating more appropriate concepts, and developing assumptions rooted in our histories and experiences. In 
other words, it requires epistemological decolonisation as a point of departure. For Santos, (Santos, B., personal communication, October 7, 2019) what is needed is a new understanding of the world and alternative thinking as the bases for transformation.

Epistemological decolonisation grounded in epistemic justice requires scrutinising the knowledges that work with its subjects and work through them. Particularly important to this aspect is Lange's (2020) suggestion that transformation implies and is derived from a variety of knowledge(s) that are usually neither explicit nor systematically examined institutionally. These include the knowledge for decolonisation (the knowledge necessary to make change possible) and the knowledge of decolonisation (the knowledge about decolonisation itself) operating in a dialectical relationship that itself needs to be examined if we are to understand the current tensions and risks of institutional and organisational transformation in the African context (Lange, 2020).

These alternative forms of knowledge are essential for constant deconstruction and reconstruction of social reality as well as social reintegration to respond innovatively, creatively, and responsively to the present and future needs of Africa. From this perspective, transformation impacts on every aspect of higher education, from governance and management to student access and support, from outreach programmes, recruitment, and retention to programme development, and from research, scholarship, and the social to teaching and learning environments.

\section{Re-imagining higher education research in Africa: Towards a conceptual framework}

In a relatively recent book chapter, an analytical framework for dealing with the decolonisation challenge, referred to as a major "epistemological and analytical break", was proposed by Cross and Ndofirepi (2017). Drawing on theoretical insights provided by West (1995), it was argued that political and epistemological decolonisation, on which transformation in higher education should rest, requires working with and through four important concepts: looking to the past for inspiration (lessons); looking inwards for individual and collective introspection (a basis for decolonising the mind); looking outwards to the increasingly dynamic surroundings and global spaces (critical engagement vis-à-vis self-ghettoisation); and looking to the present with a view to shaping the future (Cross \& Ndofirepi, 2017). Using the notion of intersecting contexts, the framework points to the different settings in which, or with reference to which, the university in Africa executes its functions. Below, we discuss the key pillars of such a project with reference to higher education research.

\section{Looking to the past: Identifying and re-thinking critical epistemic experiences embedded in the present}

Looking through the rear-view mirror is perhaps the most important source of inspiration available to human beings as they strive to shape their own future in different and better 
ways. Emphasising the role of memory, Assie-Lumumba (2018, p. 3) argued that "historical consciousness is critically important in analysing the present and in trying to find solutions for our contemporary challenges." As expressed by Clarke (1996), "History tells the people where they have been, what they have been, where they are, and what they are. Most important, history tells the people where they still must go and what they still must be" (cited in Assie-Lumumba, 2018, p. 4).

The past is the present and the future since it helps to identify, and re-think critical epistemic experiences embedded in the present and potentially in the future. History is the storage of memory, both individual and collective, ${ }^{3}$ and without memory there can be only amnesia or ignorance. From this perspective, the pervasive influences of colonial legacies in current crises facing the university in Africa can no longer be underestimated. The complicity of the university in Africa in shaping these legacies cannot be ignored. The complicity of higher education research in this process cannot be ignored. There is an urgent need to realise that coloniality has been and remains entrenched in the present-day university, and even in some of our own alternative discursive imaginations. In this regard, looking to the past offers unlimited opportunity for learning, unlearning, or re-learning deeply about the challenges confronting higher education today.

\section{Looking inwards: Decolonising the mind and its epistemic logic}

Looking inwards means understanding yourself including the use or misuse of your personal resources, or what Foucault (in Martin et al. 1988) refers to as "technologies of the self," i.e. techniques that enable individuals

to effect by their own means or with the help of others a certain number of operations on their own bodies and souls, thoughts, conduct, and way of being, so as to transform themselves in order to attain a certain state of happiness, purity, wisdom, perfection or immortality. (p. 27)

Foucault attributed two important roles to these technologies. The first is in the exercise of power, authority, and liberty. The second is the strategy through which one acts as an individual to "transform oneself into the subject of one's ethical behaviour" (Martin et al. 1988, p. 27). It is argued here that resetting these technologies goes together with the decolonisation of the mind, as articulated by Fanon $(1965,1967)$ and Biko (2002). It involves confronting the most enduring legacy of colonialism, namely epistemic violence through which the colonisers imposed themselves on the minds of the colonised to ensure that their world view manifests in the new, emerging society.

3 Individual recollections of private and social experiences are an important part of memory, and so, too, are the collective recollections of a family, and of ethnic, cultural, social and other groups. Both types of memory are important historical sources, the one often corroborating the other, thereby helping to provide a more authentic or complete data source. (The African notion of ubuntu is relevant here (see footnote 4.) However, methodological questions need to be borne in mind, such as, "How does individual memory constrain and contribute to collaborative remembering, and how do groups shape individual memory?" (Barnier \& Sutton, 2008, p. 177). 


\section{Looking outwards: An encounter with a globalising world}

There are two basic responses to the question of globalisation and its impact on the academic world, each with its own relative strengths and weaknesses. The first is the marketplace approach through which knowledge order is determined by the competitive flow of ideas, technology, values, symbols, and all cultural imagery regulated by the markets (Cross \& Cloete 1999). This approach does not account for the diversity of the world, the diversity of its experiences, and the plurality of our understandings of them.

The second reflects what West (1995) has referred to as the "go-it-alone" attitude that is strongly embedded in narrow Afrocentric research strategies, which very often call for an arrogant insularity. As West suggested "it is self-defeating, in that it usually reinforces the very inferior complexes promoted by the subtly ... mainstream" (p. 167). It would certainly risk scholars confining themselves to self-ghettoisation.

The reality is that African universities exist in the context of globalisation. They operate at the interface of both local (African) and global (Western) spaces; some imagery that we celebrate in certain discourses can no longer realistically be reclaimed. Mutual engagement through suitable dialogue and conversations between the local and the global remains a necessity, particularly when the West seems to have reached a degree of knowledge bankruptcy. In this sense, the African university is a university that takes cognisance of its African insertion in the globalising world "without losing its soul" (Downing, 2014, p. 1). This means that an epistemological break is needed in the ways in which the two worlds articulate with (or confront) each other in the knowledge domain.

\section{Looking to the present: Beyond closure and fixed frameworks}

One of the subtlest expressions of the power of coloniality in the current scholarship, including radical scholarship, resides perhaps in what appears to be an innocent attempt at calming coloniality with coloniality. By failing to acknowledge the coloniality of the very discourses that we claim to be empowering or liberating, the theories, slogans, and ideologies, such as poststructuralism, postmodernism, and postcolonialism handed down by Western science have become fossilised as unproblematic in our thinking. In the following sections, we suggest possible ways of dealing with this challenge.

\section{Revisiting and re-articulating the discursive space of the South and North}

The prevalence of Western epistemic and theoretical hegemony and Southern epistemicide (the negation of Southern modes of knowing and knowledges) still has severe consequences on the production and flows of knowledge on the continent. Complicating this situation is the fact that globalisation has stretched and scrambled the geopolitical boundaries of the South to penetrate Western social and discursive spaces. Today, what has been perceived to be the problems of the South (e.g. poverty, hunger, disease, crime, migration, violence, etc.) have also become problems of Europe and North America and this has triggered a global knowledge crisis. Christie's (2020) call for an "all-world ethics" (p. 206) of how we might live together with all others on the earth we share, has relevance; she argued that grappling 
with the legacies of colonialism and imperialism, the effects of global neoliberalism, ecological damage and climate change demand new ways of understanding and living in the world beyond perceptions of difference and beyond-human. More pointedly, Garuba (2015), asserted that fundamental change can happen only if universities rethink how the object of study itself is comprised and then reimagine it for meaningful change. At the core then, is the question of social justice, a re-ordering of power expressed through curriculum transformation and knowledge production.

\section{Disrupting the toxic agenda of Western modernity discourses}

This possible pathway lies in interrupting what Santos referred to as the "monocultures" propagated by Northern epistemologies or Eurocentric theoretical tradition that has resulted in Southern epistemicide. The first is the logic of "rigour of knowledge"-the monoculture of scientific knowledge that proclaims science to be the sole measure of truth and understanding, and the exclusive canon of production of knowledge or artistic creation. The second is the "monoculture of linear time" which proclaims that "at the cutting edge of time are to be found the core countries of the world system and, along with them, the dominant knowledges, institutions and forms of sociability" (Santos, B., personal communication, October 7, 2019). The third is the monoculture of naturalised differences that classifies people in the world into categories that naturalise hierarchies. This categorisation includes racial and sexual classification, and the perceived superiority of the white man, seen "to occur naturally, without intentional construction, and [that] renders invisible all other forms of classification, placing them beneath consideration" (Moraes \& Freire, 2017, p. 31).

\section{Reclaiming the African discursive space in the global context}

There are numerous common spaces in which we do not need to reinvent the wheel. However, the responsibility and responsive obligations of higher education to the diversity of societies and cultures in the world cannot be ignored. An important warning sign here is the need for vigilance against the adoption of decontextualised approaches and decontextualised theories that are unresponsive to local needs and challenges. In line with Mbembe (2015), there is also a need to carry our own innovations to the global stage. This will entail meticulous documenting of solutions rooted in the African experience. Therefore, when, for example, African indigenous medical cures are claimed, justifiable evidence, whether in oral or written form, should be produced at global conferences and other knowledge-sharing platforms. The recognition of diversity and its implications for a transformative epistemology also deserves attention. Sithole (2016) has argued that what should be advocated are the ecologies of knowledge leading to a pluriversalised idea of the world. Thus, it becomes incumbent on us to interrogate the historical, social, economic, and political constructs normalised in the curriculum at the level of knowledge, values, norms, symbols, and other aspects constitutive of colonial oppression, including the historically constituted system within which they continue to be reproduced (Ndlovu-Gatsheni, 2013; Suarez-Krabbe 2017). 


\section{Acknowledging the importance of epistemic vigilance}

On epistemic vigilance, Bourdieu's (1990) notion of epistemological break is instructive. He refers to three distinctive kinds of epistemic breaks. First, they entail a break from common sense or everyday life understandings, i.e., breaking from practical knowledge based on everyday experience. Second, they entail a break from the objectivist and subjectivist reductionism. For Bourdieu, subjectivity is neither determined by nor free from objective condition so researchers need to recognise their personal biases, their values, experiences, and constructions and acknowledge that these may influence the direction of their research (see Bourdieu \& Wacquant, 1992). In the words of Zondi (forthcoming, p. 266), "[T]he positionality of the thinker must be declared up front rather than hidden behind the veil of objectivity." Third, they also entail a break from theoretical knowledge that requires researchers breaking from theoretical knowledge whether subjectivist or objectivist. This can be complemented by greater sensitivity to the human dimension, more specifically, the reallife experiences of people in social theory. In South Africa, Le Cordeur (1985, p. 2) referred to the absence of the human condition in social theory as "history without politics" or "history without passion." In our case, theory without politics or passion is an epistemological approach made up of pre-determined and fixed ideas (theory) which neglect the empirical (real-life experiences of people in their diversity). Sithole (2016) also referred to this problem in his chapter, Researching the African subject in African politics.

\section{The centrality of context and the epistemic value of experience in research}

Understanding the diverse contextual complexity i.e., historical, global, local/national, and institutional influences that impact on academic practice at epistemological and pedagogical levels in higher education, is critical to research and academic practice. For example, prevalent in African communities are modes of thinking embedded in cultural values, such as the African notion of Ubuntu. ${ }^{4}$ African ontologies provide the basis for understanding reality in a relational mode in the context of the interdependence and interconnectedness of the community. They validate knowledge using communally based systems and cultural epistemic standards. Central to African ethics is also the strong orientation to collective values and harmony rooted in collective responsibility in a collective ethic that acknowledges that survival of the group is derived from harmony through interdependence and interconnectedness (Mkabela, 2005; Sarpong, 2002). The question is: "How can these experiences be reflected in African higher education research, and what difference would they make?" One proposal is to delineate the principles and implications of decolonial theoretical insights quite explicitly on, for example, the principle of knowledge relevance, its corresponding epistemological connections to the knowledges of people, their contextual life circumstances, indigenous knowledge systems, literacies, languages, and ways of knowing. Further, such connections are elucidated in research practices, recognised as ways of knowing, and made integral to the construction of decolonial theory. Thus, epistemologically, 
and theoretically, context and experience play a critical role in defining the research approach and strategies. It is through experience that the objects of study attach meaning and gain understanding of their own lives, and thus become subjects of knowledge. As Jarvis (1987, p. 164) put it, "[T]here is no meaning in a given situation until we relate our own experiences to it." Given the researcher's closeness and intimacy with experience, a degree of vigilance, indeed an epistemological break, is always required; excessive proximity constitutes as much of an obstacle to research rigour as excessive remoteness (Bourdieu, 1988).

\section{Working through and working with categories of difference}

Under colonialism, relations of domination and subordination were structured around deeply entrenched categories of social difference such as class, race, gender, ethnicity, sexual orientation, socio-economic status, nationality, and other forms of difference that, in the context of African scholarship, remain epistemological blind spots. Higher education research cannot be separated from these relations. Relationships between the subjects and objects of research are intentionally or unintentionally conditioned by the imaginary associated with these boundaries that have profound implications for knowledge conceptions, formulation, and validation. Three important precautionary measures are needed. First, an awareness or understanding of the social experiences of the researched connected to those specific divisions is of utmost importance. Second, it is important to make a distinction between the categories of social and political practice and the categories of social and political analysis used by social scientists. A question to be asked in this regard is: "Can the master's tools dismantle the master's house, or will it be a useless attempt?" (Lorde, 1984, p. 44). Hountondji (1997: 17) responded to this question with the notion of "endogenous knowledge" that he described as a knowledge approach that "creates bridges, [and] recreate[s] the unity of knowledge, or in simpler, deeper terms, the unity of the human being." Third, knowing how to deal with what Bourdieu (2003, p. 13) referred to as "original complicity" also constitutes an important distinction in knowledge production. He used this notion to refer to the researcher's historico-cultural embeddedness by virtue of class, race, gender, and other forms of social difference that may separate the researcher from the researched. In this regard, awareness and understanding of our social condition as researchers is needed. Born into one world and educated into another, how do we negotiate these intersections in research?

\section{Accounting for marginalisation and symbolic violence in knowledge representation}

Under the present politics of knowledge, where multiple knowledges exist their presence is very often concealed or discarded, either by an over-reliance on universalising or essentialising theories, or under the dynamics of power and interest (Cross, 2015). Researchers tend to project what they are used to seeing in their own social and intellectual experiences as truthful knowledge replicable in all contexts. Hence, the proliferation of silences and misrepresentation. In Audre Lorde's words (1984, p. 44): "It is not difference that immobilizes us, but silence. And there are so many silences to be broken.” And silences are directly connected to one's social and intellectual experience that always appears harmless. 


\section{Acknowledging the interplay of power and power play in higher education}

Patel (2015) remarked,

Any text and practice that aspires to be decolonial must be seen as a globally shared responsibility that is necessary but insufficient, as mapping these genealogies does not directly address the repatriation of land and alterations to material conditions. It is a 'shift of imagination.' (p. 7)

Recently a colleague made the claim that a major problem today is that "we are stuck with epistemologies." He warned that too much emphasis on the epistemological and philosophical dimensions in current African alternative discourses, without enough attention being placed on the changing role of power and power relations in higher education, remains a weakness and needs to be re-visited. ${ }^{5}$

As Bernstein (2000, p. 5) has suggested, the boundaries between different categories of social groups and knowledge are a function of power relations since "power relations create boundaries, legitimize boundaries, reproduce boundaries between different categories of groups, gender, class, race, different categories of discourse, different categories of agents." Maldonado-Torres (2007) defined coloniality as the long-standing patterns of power that emerge because of colonialism that define "culture, labour, intersubjectivity relations, and knowledge production well beyond the strict limits of colonial administrations" (p. 243). In this sense, we experience coloniality "in books, in the criteria for academic performance, in cultural patterns, in common sense, in the self-image of peoples, in aspirations of self, and so many other aspects of our modern experience" (Mignolo, 2005, p. 6).

\section{Reclaiming public good and negotiating a new moral and cultural ground in higher education}

The encroachment of marketisation and the profit motive into the African academy has had damaging effects (academic moonlighting, commodification, and marketisation of higher education) on the African university. For Slaughter and Leslie (1997, p. 210), it represents "a shift from a public good knowledge/learning regime to an academic capitalist knowledge/learning regime" in which students become consumers and institutions the marketers. This trend is reflected in recent higher education literature in the abundance of epithets used to characterise the present-day university such as the "academic capitalism" to which Münch (2014) and Slaughter and Rhoades ( 2008) refer in the titles of their works; the "exchange university" and the "corporatization of academic culture" to which Chan and Fisher (2009) refer in their book title, and Gmelch's (1994) take on the transition from "Homo Academicus to Homo Oeconomicus" inspired by nostalgia for the old days when knowledge concerns prevailed over profiteering. There is a need to be vigilant about the

5 In South Africa, for example, much remains to be done in the transformation of power relations in higher education, in both its representation of the demographic profile of the country, and in having an Africa-centred knowledge/research paradigm. As Seepe (2017) proposed, besides increasing participation of African/black scholars in academia, there needs to be a deconstruction of the dominant paradigm and the development of an African-based knowledge production and research agenda. 
profound consequences of this movement in African higher education. The conception of education as a public good is under attack, so a new ethical and moral ground in higher education research is required for the common good, particularly at the political juncture where it appears under siege from the neo-liberal market pressures. There is a need to produce knowledge and knowledge practitioners capable of "generating home-grown solutions for African problems while also drawing from global human experiences" (NdlovuGatsheni, 2016, p. 41).

\section{Conclusion}

Knowledge is historically and socially situated. It emerges and rises to prominence in a particular philosophical and historical context that, in the case of Africa, has been and remains under colonial bondage. In this regard, we have argued that the notion of decolonisation needs to be reclaimed in current scholarship. Without renewed efforts at decolonisation, social justice cannot be fully addressed on the continent.

We have outlined a conceptual framework that could inform higher education research meaning making and practices in Africa. By looking to the past, the value of recognising the dehumanising results and effects of colonial knowledge production is foregrounded, while the strengths and weaknesses of a rich epistemological and theoretical legacy of African postindependence scholarship as a source of inspiration, is acknowledged. In looking inwards, the value of individual and social introspection is highlighted, given the colonial and apartheid impact on people's minds in terms of the structures, modes of operation, and contents. In looking outwards lies the challenge of engaging with an increasingly complex and reconfigured global space in which globalisation pre-determines the common place of ideas and knowledge through market forces, inevitably under the knowledge patronage system of the West, and increasingly mediated by new dynamics, such as the Fourth Industrial Revolution and pandemics. Finally, in looking to the present, the framework offers possibilities for upending the subtle prevalence of coloniality in all spheres of academic practice with a view to shaping the future. This involves embracing the concepts of knowledge embeddedness and responsiveness and moving beyond closure and fixed frameworks.

In essence, we point to a new way of thinking about knowledge construction, one that can serve as a basis for developing new theoretical and epistemological insights, founded on inclusivity and social justice. The alternative thinking and alternative epistemology we propose is premised on four conditions: attention to context, epistemology, theory, and methodology; revisiting concepts and assumptions with reference to history, context, and experience; thinking grounded in epistemic justice; and scrutinising the knowledges, that is, knowledge for decolonisation (to make change possible) and knowledge of decolonisation (about decolonisation itself). It is a call for epistemological decolonisation as a point of departure to enable social justice. 
The future of tertiary education must be located within a new horizon of possibilities, informed by a new political epistemology and ontology, embedded in the complex African experience and cultural web of visibility of the colonised, marginalised, or oppressed. In short, there can be no social justice without epistemic justice.

\section{References}

Amin, S. (1972). Underdevelopment and dependence in black Africa-Origins and contemporary forms. The Journal of Modern African Studies, 10(4), 503-524.

Archibald, J., Lee-Morgan, J., \& De Santolo, J. (Eds.) (2019). Decolonising research: Indigenous storywork as methodology. ZedScholar.

Asante, M. K. (1987). The Afrocentric idea. Temple University Press.

Asante, M. K. (2015). African pyramids of knowledge: Kemet, Afrocentricity and Africology. Universal Write Publications.

Assié-Lumumba, N. (2018, August 2). Africa and the advancement of higher education at home and globally: Memory and imperative for renewal through purposeful fusion [Keynote speech]. 3rd Annual Eric Molobi Memorial Lecture. University of Johannesburg, South Africa.

Barnier, A. J., \& Sutton, S. (2008). From individual to collective memory: Theoretical and empirical perspectives. MEMORY, 16(3), 177-182.

https://dx.doi.org/10.1080/09541440701828274

Barreto, J. (2014). Epistemologies of the South and human rights: Santos and the quest for global and cognitive justice. Indiana Journal of Global Legal Studies, 21(2), 395492. https://doi.org/10.2979/indjglolegstu.21.2.395

Bernstein, B. B. (2000). Pedagogy, symbolic control, and identity: Theory, research, critique (Rev. ed.). Rowman \& Littlefield.

Biko, S. (2002). I write what I like. Selected writings. University of Chicago Press.

Bourdieu, P. (1972). Outline of a theory of practice. Cambridge University Press.

Bourdieu, P. (1988) Homo academicus. Polity.

Bourdieu, P. (1990). In other words: Essays towards a reflexive sociology. Stanford University Press.

Bourdieu, P. (2003). Colonialism and ethnography: Foreword to Pierre Bourdieu's Travail et travailleurs en Algérie. Anthropology Today, 19(2), 13-18. https://doi.org/10.1111/1467-8322.00177 
Bourdieu, P., \& Wacquant, L. (1992). An invitation to reflexive sociology. Polity.

Branch, A., \& Mapilly, Z. (Eds.) (2015). Africa uprising: Popular protest and political change. HSRC Press.

Chan, A. S., \& Fisher, D. (2009). The exchange university: Corporatization of academic culture. UBC Press.

Chilisa, B. (2012). Indigenous research methodologies. SAGE Publications.

Christie, P. (2020). Decolonising Schools in South Africa: The Impossible Dream? London: Routledge.

Cochran, P. A. L., Marshall, C. A., \& Garcia-Downing, C. (2008). Indigenous ways of knowing: Implications for participatory research and community. American Journal of Public Health, 98(1), 22-27.

Cossa, J. A. (2009). African renaissance and globalization: A conceptual analysis. Ufahamu: A Journal of African Studies, 36(1), 1-25.

Cross, M. (2015). State power, transition and new modes of coordination in higher education in South Africa. In S. Schwartzman, R. Pinheiro \& P. Pillay (Eds.) Higher education in the BRICS Countries: Investigating the pact between higher education and society (pp. 353-378). Springer.

Cross, M., \& Cloete, N. (1999). Avoiding closure and challenging frameworks. In M. Cross, N. Cloete, E. Beckham, A. Harper, J. Indiresan \& C. Musil (Eds.), The role of higher education in building democracy—2nd Tri-Nation Campus Diversity Seminar (pp. 192-205). Maskew Miller Longman.

Cross, M., \& Ndofirepi, A. (2017). Beyond closure and fixed frameworks. In M. Cross \& A. Ndofirepi (Eds.), Knowledge and change in African universities (Vol. 2): Reimagining the terrain (pp.189-194). Sense.

Datta, R. (2018). Decolonising both researcher and research and its effectiveness in Indigenous research. Research Ethics, 14(2), 1-24.

Denzin, N. K., Lincoln, Y. S., \& Smith, L. T. (Eds.) (2008). Handbook of critical and indigenous methodologies. SAGE.

Devisch, R., \& Nyamnjoh F. B. (Eds.). (2011). The postcolonial turn: Re-imagining anthropology and Africa. Langaa RPCIG.

Diop, C. A. (1954). Precolonial Black Africa. Éditions Présence Africaine.

Downing, K. (2014). Aligning strategy with rankings without selling your institutional soul. Paper presented at the University of Johannesburg, South Africa. 
Fanon, F. (1965). The wretched of the earth. Grove Press. (Original French edition published 1961)

Fanon, F. (1967). Black skin, white masks. Grove Press. (Original French edition published 1952)

Fataar, A. (2018, October). (How) can decoloniality inform "educational (curriculum) knowledge" selection? [Paper presentation]. South African Education Research Association (SAERA) Conference 2018, Pretoria, RSA.

Garuba, H. (2015). What is an African Curriculum? Mail \& Guardian, 7 April. https://mg.co.za/article/2015-04-17-what-is-an-african-curriculum/

Gmelch, W. H. (1994). Five skills for becoming a more effective team leader. Washington State University Press.

Goody, J. (2006). The theft of history. Cambridge University Press.

Grosfoguel, R. (2007). The epistemic decolonial turn: Beyond political-economy paradigms. Cultural Studies, 21(2/3), 203-46. https://doi.org/10.1080/09502380601162514

Harvey, D. (1989). The condition of postmodernity: An enquiry into the origins of cultural change. Blackwell.

Heleta, S. (2016). Decolonisation of higher education: Dismantling epistemic violence and eurocentrism in South Africa. Transformation in Higher Education, 1(1), a9. https://dx. doi.org/10.4102/the. v1i1.9

Hountondji, P. (1983). African philosophy: Myth and reality. Indiana University Press.

Hountondji, P. (1997). Endogenous knowledge: Research trails. CODESRIA.

Hountondji, P. (2002). The struggle for meaning: Reflections on philosophy, culture and democracy in Africa. Ohio University Press.

Hountondji, P. (2013). L'Ancien et le nouveau: La production du savoir dans l'Afrique d'aujourd'hui [The old and the new: Knowledge production in today's Africa]. Langaa RPCIG.

Jarvis, P. (1987). Meaningful and meaningless experience: Towards an analysis of learning from life. Adult Education Quarterly, 37, 164-172.

Ki-Zerbo, J. (1994). Histoire de l'Afrique noire. Hatier.

Lange, L. (2020). Transformation revisited: Twenty years of higher education policy in South Africa. In I. Rensburg, S. Motala \& M. Cross (Eds.), Transforming universities in South Africa: Pathways to higher education reform (pp. 39-59). Brill. 
Le Cordeur, B.A. (1985). The reconstruction of South African history. Presidential address delivered to the tenth biennial conference of the South African Historical Society at the University of Cape Town, 1985.

Lorde, A. (1984). Sister outsider: Essays and speeches. Crossing Press.

Maldonado-Torres, N. (2007). On the coloniality of being: Contributions to the development of a concept. Cultural Studies, 21(2-3), 243.

Manyi, F., \& Ekine, S. (2012). African awakening: The emerging revolutions. Pambazuka Press.

Martin, L. H., Gutman, H., \& Hutton, P. (Eds.). (1988). Technologies of the self: A seminar with Michel Foucault. Tavistock.

Mawere, M. (2011). African belief and knowledge systems: A critical perspective. Langaa RPCIG.

Mazama, A. (2001). The afrocentric paradigm: Contours and definitions. Journal of Black Studies, 31(4), 387-405.

Mazrui, A. A. (1986). The Africans: A triple heritage. BBC Publications.

Mbembe, A. (2015). Decolonising knowledge and the question of the archive. Public lecture given at the Wits Institute for Social and Economic Research (WISER), University of the Witwatersrand, Johannesburg, RSA.

https://wiser.wits.ac.za/system/files/Achille\%20Mbembe\%20-

$\%$ 20Decolonizing $\% 20$ Knowledge\%20and\%20the $\% 20$ Question $\% 20$ of $\% 20$ the $\% 20$ Arc hive.pdf

Mignolo, W. D. (2005). The idea of Latin America. Blackwell Publishing.

Mignolo, W. D. (2007a). Introduction: Coloniality of power and de-colonial thinking. Cultural Studies, 21(2-3), 155-167. https://doi.org/10.1080/09502380601162498

Mignolo, W. D. (2007b). Delinking: The rhetoric of modernity, the logic of coloniality and the grammar of de-coloniality. Cultural Studies, 21(2-3), 449-514.

Mignolo, W. D. (2011). The darker side of Western modernity: Global futures, decolonial options. Duke University Press.

Mignolo, W. D., \& Escobar, A. (Eds.) (2010). Globalization and the decolonial option. Routledge. https://doi.org/10.4324/9781315868448 
Mignolo, W. D., \& Vázquez, R. (2013). Decolonial aesthesis: Colonial wounds/decolonial healings. Social Text: Periscope (online journal).

http://socialtextjournal.org/periscope_article/decolonial-aesthesis- colonial-woundsdecolonial-healings/

Mkabela, Q. (2005). Using the Afrocentric method in researching indigenous African culture. The Qualitative Report, 10(1), 178-89.

Moraes, S. E., \& Freire, L. de A. (2017). Planetary citizenship and the ecology of knowledges in Brazilian universities. International Journal of Development Education and Global Learning, 8(3), 25-42.

Mudimbe, V. Y. (1985). African philosophy as an ideological practice: The case of Frenchspeaking Africa. African Studies Review, 28(2-3), 149-233.

Mudimbe, V. Y. (1988). The invention of Africa: Gnosis, philosophy, and the order of knowledge. Indiana University Press.

Münch, R. (2014). Academic capitalism: Universities in the global struggle for excellence. Routledge.

Nabudere, D. W. (2011a). Afrikology, philosophy and wholeness. An epistemology. African Institute of South Africa.

Nabudere, D. W. (2011b). Archie Mafeje: Scholar, activist and thinker. African Institute of South Africa.

Ndlovu-Gatsheni, S. J. (2013). Empire, global coloniality and African subjectivity. Berghahn Publications.

Ndlovu-Gatsheni, S. J. (2014). Global coloniality and the challenges of creating African futures. Strategic Review for Southern Africa, 36(2), 181-202.

Ndlovu-Gatsheni, S. J. (2016). The imperative of decolonizing the modern westernized university. In S. J. Ndlovu-Gatsheni \& S. Zondi (Eds.), Decolonising the university, knowledge systems and disciplines in Africa (pp. 27-43). Carolina Academic Press.

Ndlovu-Gatsheni, S. J. (2018a). Epistemic freedom in Africa: Deprovincialization and decolonization. Routledge.

Ndlovu-Gatsheni, S. J. (2018b). The dynamics of epistemological decolonization in the 21st century: Towards epistemic freedom. Strategic Review for Southern Africa, 40(1), $16-45$.

Oparinde, K., \& Govender, V. (2019). "Postgraduateness"-A project for constructing a renaissance Africa: A decolonial approach. Education as Change, 23. https://doi.org/10.25159/1947-9417/5096. 
Oyebade, B. (1990). African studies and the Afrocentric paradigm: A critique. Journal of Black Studies, 21(2), 233-238. https://www.jstor.org/stable/2784476

Patel, L. (2015). Decolonising educational research: From ownership to answerability. Routledge. https://doi.org/10.4324/9781315658551

Quijano, A. (2000). Coloniality of power, Eurocentrism and Latin America. Duke University Press.

Rivenburgh, N. K., \& Manusov, V. (2010). Decentering as a research design strategy for international and intercultural research. The Journal of International Communication, 16(1), 23-40. https://doi.org/10.1080/13216597.2010.9674757

Rodney, W. (1972). How Europe underdeveloped Africa. Bogle L'Ouverture Publications.

Santos, B. de S. (Ed.). (2007). Another knowledge is possible: Beyond Northern epistemologies. Verso.

Santos, B. de S. (2014). Epistemologies of the South: Justice against epistemicide. Routledge.

Santos, B. de S., Nunes, J. A., Meneses, M. P. (2007). Introduction: Opening up the canon of knowledge and recognition of difference. In B. S. Santos (Ed.), Another knowledge is possible: Beyond Northern epistemologies (pp. xix-1xii). Verso.

Sarpong, P. (2002). Peoples differ: An approach to inculturation in evangelization. SubSaharan.

Schiele, J. H. (1994). Afrocentricity: Implications for higher education. Journal of Black Studies, 25(2), 150-169. https://www.jstor.org/stable/2784459

Seepe, S. (2017). Higher education transformation in South Africa. In M. Cross \& A. Ndofirepi (Eds.), Knowledge and change in African universities (Vol.1) (pp. 121143). Sense.

Seroto, J. (2018). Dynamics of decoloniality in South Africa: A critique of the history of Swiss Mission education for Indigenous People. Studia Historiae Ecclesiasticae, 44(3), 14 pages. https://doi.org/10.25159/2412-4265/3268.

Shivji, I. G. (1976). Class struggles in Tanzania. Heinemann.

Simpson, L. (2001). Aboriginal peoples and knowledge: Decolonising our processes. Canadian Journal of Native Studies, 21(1), 137-148.

Sithole, T. (2016). Ontology and the lacking African subject. In S. J. Ndlovu-Gatsheni \& S. Zondi (Eds.), Decolonising the university, knowledge systems and disciplines in Africa (225-228). Carolina Academic Press. 
Slaughter, S., \& Leslie, L. (1997). Academic capitalism: Politics, policies, and the entrepreneurial university. John Hopkins University Press.

Slaughter, S., \& Rhoades, G. (2008). The academic capitalist knowledge/learning regime. In A. S. Chan \& D. Fischer (Eds.), The exchange university: Corporatization of academic culture (pp. 19-48). University of British Columbia Press.

Smith, L. T. (1999). Decolonising methodologies. Research and Indigenous Peoples (1st ed.). University of Otago Press.

Smith, L. T. (2005). On tricky ground: Researching the native in the age of uncertainty. In N. K. Denzin \& Y. S. Lincoln (Eds.), The SAGE Handbook of Qualitative Research (pp. 113-144). SAGE.

Smith, L.T. (2012). Decolonising methodologies. Research and Indigenous Peoples (2nd ed.). Zed Books.

Suarez-Krabbe, J. (2017). The conditions that make a difference: Decolonial historical realism and the decolonisation of knowledge and education. In: Cross, M. \& Ndofirepi, A. (Eds.) Knowledge and change in African universities (Vol. 1) (pp. 5980). Sense.

wa Thiong'o, Ngugi. (2009). Re-membering Africa. East African Educational Publishers Ltd.

wa Thiong'o, Ngugi. (2012). Globalectics: Theory and the politics of knowing. Columbia University Press.

Waghid, Y. (2017). Ubuntu: African philosophy of education and pedagogical encounters. In M. Cross \& A. Ndofirepi (Eds.), Knowledge and change in African universities (Vol.1) (pp. 29-40). Sense.

West, C. (1995). The new cultural politics of difference. In J. Rajchman (Ed.), The identity question (pp. 147-172). Routledge.

Yew-Siong, L., \& Ally, Y. (2020). "Getting a seat at the table" during the Covid-19 Pandemic: Indigenous knowledge systems and healthcare decision-making. The Perspective Online, Special Edition COVID-19 in Higher Education, 2(1/2), 11-20.

Zavala, M. (2013). What do we mean by decolonising research strategies? Lessons from decolonising Indigenous research projects in New Zealand and Latin America. Decolonization: Indigeneity, Education \& Society, 2(1), 55-71.

Zeleza, P. T. (1997). Manufacturing African studies and crises. CODESRIA.

Zondi, S. (Forthcoming). Protests and pursuits: The South African university in turmoil and the search for a decolonial turn. In C. Brink (Ed.) The Responsive university and the crisis in South Africa (pp. 263-294). Brill Sense. 